Vol. 8, Issue 8, August 2021

DOI: 10.17148/IARJSET.2021.8818

\title{
A Correlational Study of Emotional Intelligence and Resilience among young adults during covid- 19 pandemic
}

\author{
Mrs. Seethalakshmy.A ${ }^{1}$, Kowsalya $\mathrm{M}^{2}, \mathrm{P}$ R Koushikha ${ }^{3}$, Pratiksha.V ${ }^{4}$, Madhumitha. ${ }^{5}$ \\ ${ }^{1}$ Assistant Professor, Department of Psychology, Sri Krishna Arts and Science College, Coimbatore, Tamil Nadu \\ ${ }^{2-5}$ UG - Psychology, Sri Krishna Arts and Science College, Coimbatore, Tamil Nadu
}

\begin{abstract}
Human being is a social animal. According to Aristotle, the Social life or the Society is something that precedes the individual. Emotional intelligence plays a major role in an individual, for a successful social life. Life of an individual are not always smooth, there can be stressful situations or crisis. Resilience refers to the ability of a person to adapt and bounce back in times of adversity. A person can cope and bounce back from an adversity, only when he develops resilience. Even though many previous research have proved that a person having higher Emotional intelligence will be able to develop higher resilience in adverse life situations. The current research studies on the role of Emotional Intelligence on Resilience among young adults during the Covid 19 Pandemic, which is one of the worst disaster of today's world. The study is carried out with sample of 109 young adults, inclusive of both Gender between the age group of 18-25. The study was carried out in the state of Tamilnadu which is one of the Covid-19 worst hit area in India. Data was collected with the respective questionnaires. Nicholson McBride Resilience questionnaire (NMRQ) developed by McBride (2010) and Schutte Self report Emotional Intelligence test (SSEIT) developed by Dr.NicolaSchutte. The statistical analysis such as Correlation and Regression revealed significant relationships between Emotional Intelligence and Resilience among young adults. Hence the study concludes that being resilient requires one to be emotionally intelligent and become emotionally resilient even during this pandemic tough time. A numerous methods and strategies are discussed in this paper on improving the Emotional Intelligence of Young adults and thereby their Resilience. The study contributes to the literature knowledge on the relationship of Emotional Intelligence and Resilience among young adults during Covid -19 Pandemic.
\end{abstract}

Keywords: Emotional Intelligence, Resilience, Covid -19 Pandemic

\section{INTRODUCTION}

One of the worst situation the world has faced in the recent time is Covid -19 Pandemic. Though the effects of the pandemic are already taking a devastating toll on millions of people, the heart-breaking impact is on Young adults. It has a major impact not only on their jobs and employment prospects, but also have disrupted their education and training and finally on their mental well-being. Resilient people are able to utilize their skills and strengths to cope and recover from problems and challenge especially in this pandemic. Mental outlook allows them to work through their negative feelings and recover. When one is able to work on their feelings directs to the concept of Emotional Intelligence. Emotional Intelligence defined as the ability to monitor one's own and others' feelings and emotions, to discriminate among them and to use this knowledge to guide one's actions and thinking ( Salovey and Mayer, 1990).

Emotional intelligence produces a positive impact and helps a person to success, impacts his quality of life, and relationships as their life progresses. A person who can understand themselves well, and who know how to relate to and connect with others, often be the happier, will be more self-confident and fruitful. In adverse situations, emotional intelligence could be much more powerful than IQ and helps in predicting success in life (Goleman, 1995). Emotional Intelligence hence is a major factor affecting the resilience of an Individual. When a person possess good social and relational skills, he will be able to handle unexpected and unfortunate circumstances by being self-aware, and socially 


\section{International Advanced Research Journal in Science, Engineering and Technology}

Vol. 8, Issue 8, August 2021

DOI: 10.17148/IARJSET.2021.8818

adapting and empathetic. Hence Increased Emotional Intelligence may lead to increased adaptability (Akerjordet et.al, 2007) and become highly resilient.

Emotionally Intelligent people know how to provide empathy to the people around them even during the time of crisis. Thus when they become supportive and compassionate to the people around them, that will create a positive impact and they feel stronger and resilient. A study on Emotional Intelligence and Resilience among adults has shown a positive correlation (Kadambari \& Singh Swati, 2015). Hence the current research concentrates on the Emotional Intelligence exhibited by young adults and the concept of resilience which is the ability of individuals to cope despite risk of pandemic.

\section{Aim}

The major objective of the research is to find the relationships between Emotional Intelligence and Resilience among Young adults during Covid -19 Pandemic. The study concentrates on the correlation between Emotional Intelligence and Resilience of Young adults aged 18-25 years.

\section{EXPERIMENTAL METHODS OR METHODOLOGY}

\section{Hypothesis}

- $\quad \mathrm{H}_{1}$ : Among Young Adults, there exists positive correlation between Emotional Intelligence and Resilience

- $\mathrm{H}_{2}$ : Among Female Young Adults, there exists positive correlation between Emotional Intelligence and Resilience

- $\quad \mathrm{H}_{3}$ : Among Male Young Adults, there exists positive correlation between Emotional Intelligence and Resilience Sampling

Participants in this study consists of 109 Young adults between 18-25 years. The sample was drawn from Young population of various districts of TamilNadu, India. Simple Random sampling method is used. Both Male and Female gender are included in the sample.

\section{Measures}

The following instruments were used to collect data from the sample:

Demographic details were collected initially in a Persona Data Questionnaire designed by the Researcher. For the purpose of the study, to collect the Emotional Intelligence data The Schutte Self Report Emotional Intelligence Test (SSEIT) scale was used. The scale contains 33 item self-report measure of emotional intelligence developed by Schutte et al in 1998 . The tool uses the 5-point Likert scale to respond to the statement from strongly disagree to strongly agree. To calculate a scale score, reverse code responses to items 5, 28, and 33 is taken along with other item scores. The Emotional Intelligence mainly concentrates on three aspects assessment and expression, regulation and manipulation of emotions. The scale has high reliability with Cronbach's alpha coefficients ranging between 0.73 and 0.92 .

For measuring Resilience, Nicholson McBride Resilience Questionnaire developed by McBride (2010) is used. This is a tool of 12 items and uses 5 -point Likert scale from $1=$ strongly disagree to $5=$ strongly agree. The scale has a high reliability with Cronbach's Alpha $=0.76$.

\section{RESULTS AND DISCUSSION}

Table-1: Correlation between Emotional Intelligence and Resilience among young adults. 
Vol. 8, Issue 8, August 2021

DOI: $10.17148 / I A R J S E T .2021 .8818$

\begin{tabular}{|c|c|c|c|}
\hline & & $\begin{array}{l}\text { Emotional } \\
\text { Intelligence }\end{array}$ & Resilience \\
\hline Emotional Intelligence & $\begin{array}{l}\text { Pearson Correlation } \\
\text { Sig. (2-tailed) } \\
\text { N }\end{array}$ & $\begin{array}{l}1 \\
109\end{array}$ & $\begin{array}{l}.604^{* *} \\
.000 \\
109\end{array}$ \\
\hline Resilience & $\begin{array}{l}\text { Pearson Correlation } \\
\text { Sig. (2-tailed) } \\
\text { N }\end{array}$ & $\begin{array}{l}.604^{* *} \\
.000 \\
109\end{array}$ & $\begin{array}{l}1 \\
109\end{array}$ \\
\hline
\end{tabular}

** Correlation is significant at the .01 level (2-tailed)

Table-1 indicates among young adults Emotional shows a significant relation on Resilience. Any variable correlated with itself have a correlation of 1 . When one variable increases in the value, the second variable also increases. This is called positive correlation. From Pearson correlation table young adults Emotional Intelligence correlation is 0.604 with Resilience. Hence, we can conclude that when Emotional Intelligence increases, Resilience also increases. We get the pvalue of 0.000 is less than significance level, so we would reject the null hypothesis. Since p-value is $<0.01$ there is a statistically significant correlation between the two variables Emotional Intelligence and Resilience.

Table - 2: Result of linear Regression analysis between Emotional Intelligence and Resilience among young adults

\begin{tabular}{|l|r|r|r|r|}
\hline & & & & \\
\hline \\
Model & $\mathrm{R}$ & R Square & Adjusted R Square & \multicolumn{2}{c|}{$\begin{array}{c}\text { Std. Error of the } \\
\text { Estimate }\end{array}$} \\
\hline 1 & .604 & .364 & .358 & 3.893 \\
\hline
\end{tabular}

a. Predictors: (Constant), EMOTIONALINTELLIGENCE

Table-2 provides the $\mathrm{R}$ and $\mathrm{R}^{2}$ values. The $\mathrm{R}$ values represents the simple correlation and is 0.604 , which indicates high degree of correlation. The $\mathrm{R}^{2}$ value indicates how much of the total variation in the dependent variable, can be explained by the independent variable. The output of first table shows that model summary. We find that the adjusted $\mathrm{R}^{2}$ of the model is 0.358 with $\mathrm{R}^{2}=0.364$ that means the linear regression explains $36.4 \%$ of variance in the data. In this case $36.4 \%$ can be explained which is large.

Table - 3: Result of ANOVA

\begin{tabular}{|ll|r|r|r|r|r|}
\hline \multicolumn{1}{|c|}{ ANOdel $^{2}$} & Sum of Squares & df & Mean Square & \multicolumn{1}{c|}{ F } & \multicolumn{1}{c|}{ Sig. } \\
\hline 1 & Regression & 929.367 & 1 & 929.367 & 61.338 & $.000^{\mathrm{b}}$ \\
& Residual & 1621.220 & 107 & 15.152 & & \\
& Total & 2550.587 & 108 & & & \\
\hline
\end{tabular}

a. Dependent Variable: RESILIENCE

b. Predictors: (Constant), EMOTIONALINTELLIGENCE

The table of ANOVA is f test, linear regression's f-test has the null hypothesis that there is no linear relationship between the two variables Emotional Intelligence among young adults and Resilience With $\mathrm{f}=61.338$ and 108 degree of freedom 


\section{International Advanced Research Journal in Science, Engineering and Technology}

Vol. 8, Issue 8, August 2021

DOI: $10.17148 /$ IARJSET.2021.8818

that the test is highly significant, thus we can assume that there is linear relationship between the variables in the model. This table indicates that the regression model predicts the dependent variable significantly well. This indicates the statistical significance of the regression model that was run. Here, $p<0.0005$ which is less than 0.05 , and it indicates the overall the regression model statistically significantly predicts the outcome variable.

\section{Figure - 1:}

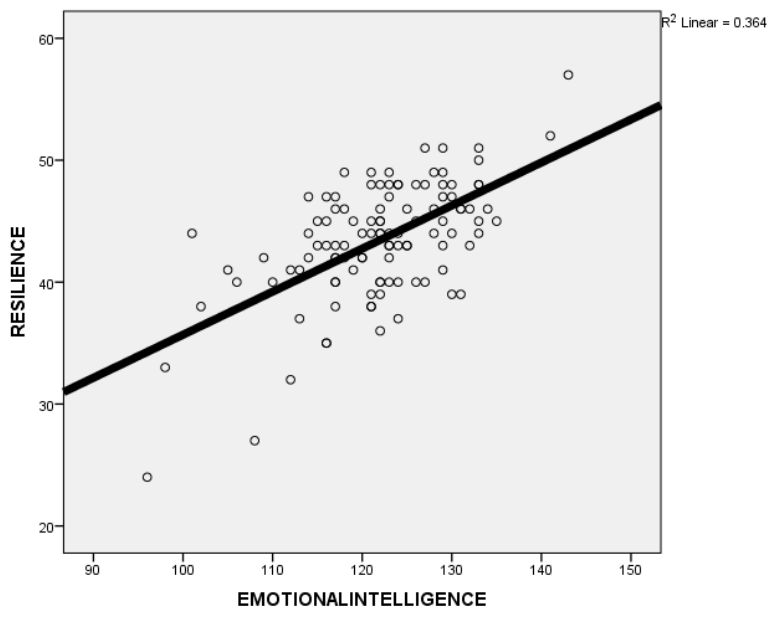

The graph represents the liner relationship between the independent variable and dependent variables. As the emotional Intelligence Increases, so do the Resilience in Young adults..

Table - 4: Gender Base d Correlation between Emotional Intelligence and Resilience among young adults.

Correlations

\begin{tabular}{|c|c|c|c|c|}
\hline GENDER & & & $\begin{array}{c}\text { Emotional } \\
\text { Intelligence }\end{array}$ & Resilience \\
\hline \multirow[t]{6}{*}{ MALE } & Emotional Intelligence & Pearson Correlation & 1 & $.657^{* * *}$ \\
\hline & & Sig. (2-tailed) & & .002 \\
\hline & & $\mathrm{N}$ & 20 & 20 \\
\hline & Resilience & Pearson Correlation & $.657^{* * *}$ & 1 \\
\hline & & Sig. (2-tailed) & .002 & \\
\hline & & $\mathrm{N}$ & 20 & 20 \\
\hline \multirow[t]{6}{*}{ FEMALE } & Emotional Intelligence & Pearson Correlation & 1 & $.595^{* *}$ \\
\hline & & Sig. (2-tailed) & & .000 \\
\hline & & $\mathrm{N}$ & 88 & 88 \\
\hline & Resilience & Pearson Correlation & $.595^{* * *}$ & 1 \\
\hline & & Sig. (2-tailed) & .000 & \\
\hline & & $\mathrm{N}$ & 89 & 89 \\
\hline
\end{tabular}

**. Correlation is significant at the 0.01 level (2-tailed). 


\section{International Advanced Research Journal in Science, Engineering and Technology}

Vol. 8, Issue 8, August 2021

DOI: 10.17148/IARJSET.2021.8818

From Table-4, we can conclude that in the case of Young Male adults, the Pearson Correlation obtained is 0.657 which indicates a positive relation on their Emotional Intelligence and Resilience. Hence, we can conclude that when Emotional Intelligence increases, Resilience also increases. But we get the p-value of 0.002 is greater than significance level, so we would accept the null hypothesis. Since p-value is $>0.01$ there is no statistically significant correlation between the two variables Emotional Intelligence and Resilience in the case of Young Male adults.

But for the Young Female adults, the Pearson Correlation obtained is 0.595 which indicates a positive relation on their Emotional Intelligence and Resilience. So Emotional Intelligence increases, Resilience also increases. But we get the pvalue of 0.000 is less than significance level, so we would reject the null hypothesis. Since p-value is $<0.01$ there is statistically significant correlation between the two variables Emotional Intelligence and Resilience in the case of Young Female adults.

\section{DISCUSSION}

The aim of this study was to find the relationships between Emotional Intelligence and Resilience among Young adults during Covid -19 Pandemic. This study focuses mainly on emotional intelligence and resilience of Young adults. During the Covid-19 pandemic, if the young adults are capable of overcoming adversity and recognizing their own and other people's emotions, controlling them and projecting them in an appropriate way that can help them to get a series of adaptive behaviors which in turn will help to adopt healthy life habits ( Brown et.al, 2001).

The present study among 109 population, there were 89 Females and 20 Males. Statistical Analysis of the collected data revealed a positive correlation between Emotional Intelligence and Resilience. The result concluded that greater the Emotional intelligence of an adult, greater will be the Resilience. More over as the p-value was less than 0.01 indicating a statistically significant correlation between the two variables Emotional Intelligence and Resilience.

From the regression test, in Table-2 it shows that there is positive correlation between the independent variable and dependent variable. The value of independent variable $\mathrm{R}=0.604$, the mean of total variation in dependent variable is 0.364. For table the Scatterplot is normally distributed for 109 population among the young adults for Emotional Intelligence and Resilience. Form significance value we conclude that there is variation in response. The graph-1 represents the liner relationship between the independent variable and dependent variables. Hence we the study concludes that greater the emotional Intelligence, greater the resilience. Thus the results of the current study are in accordance with the results of previous studies, as emotional intelligence can contribute to the satisfactory adaptation to the different eventualities of life and to the development of a set of meta-qualities that can be practiced, learned, and applied to the capacity for recovery (Goleman, 2011).

Among Females, there observed a significant correlation between the two variables, Emotional Intelligence and Resilience. Among Males, though there is a positive relation between the variables, the correlation is not significant. This may be due to the low count of Males in the selected population.

Hence the research concludes on the fact that, among Young adults, if the Emotional Intelligence is improved, there will be a major increase in Resilience. It has been observed in various research that Resilience act as a positive link to motivation (Magnano et.al, 2016), performance (Wong, 2008) and positive emotions (Cohn, 2009). Hence how adverse the situation be, the young adults will be able to handle it. This appeared to be true among young adults during the Covid19 Pandemic.

By taking responsibility, feeling empathy and staying calm and in control help one to improve in difficult situations. By self-evaluation, Self-regulation, self-expression one can always develop their emotional Intelligence and thereby enhance 


\section{International Advanced Research Journal in Science, Engineering and Technology}

Vol. 8, Issue 8, August 2021

DOI: 10.17148/IARJSET.2021.8818

mental well-being on a day-to-day basis. This helps the individual to be more resilient. If we don't allow circumstances to get the best of us and keep us down, we ourselves can rise up above the times of trial and also believe that we can survive and even thrive because we have endured struggles. We should not be broken by circumstances, instead we should feel that the big picture of our life is much more than our specific circumstances, then we can control and manage the intensity of our emotions and become more resilient.

\section{CONCLUSION}

The current study showed that there is positive correlation between Emotional Intelligence and Resilience among young adults. It is the Resilience that helps a person to bounce back when life presents challenges. And when the world face the challenge of Covid -19 pandemic, among young adults, the resilience played a major role. And when the Young adult, irrespective of Gender difference possess high Emotional Intelligence that helped them to have higher Resilience and overcome the adverse situation. So, it's necessary for an individual to have a better Emotional Intelligence for facing various life challenges.

\section{LIMITATIONS AND FUTURE IMPLICATIONS OF THE RESEARCH}

The limitation in the research is the study was a correlational study. The study makes use of non-experimental method for data collection. The age group of the study was limited. The future implications of the research are the study can be done for a larger population over a longer period of time for extensive results. The study was carried out with during the Covid Pandemic. In future, Interventional method to improve Emotional Intelligence and there by the improvement in Resilience can be studied.

\section{IMPLICATIONS}

The present study implies that it is necessary to know the importance of Emotional Intelligence. Emotional intelligence contributes to an individual's ability to appraise situations in a constructive way, and thus result in better outcomes and wellbeing. This study would help to get an idea of how consequences of emotional intelligence are a sense of adaptive resilience in times of future stressful circumstances.

\section{REFERENCES}

1. Akerjordet K., Severinsson E. Emotional intelligence: A review ofthe literature with specific focus on empirical and epistemologicalperspectives. J. Clin. Nurs. 2007;16:1405-1416. doi: 10.1111/j.1365-2702.2006.01749.x.

2. Allen, A.N.; Kilgus, S.P.; Eklund, K. An Initial Investigation of the Efficacy of the Resilience Education Program (REP). Sch. Ment. Health 2019, 1, 163-178.

3. Bacon, A.M.; Corr, P.J. Motivating emotional intelligence: A reinforcement sensitivity theory (RST) perspective. Motiv. Emot. 2017, 2, $254-264$

4. Brown, J.H.; D'Emidio-Caston, M.; Benard, B. Resilience Education; Corwin Press: Thousand Oaks, CA, USA, 2001

5. Clarke J, Nicholson J. Resilience: bounce back from whatever life throws at you. Hachette UK; 2010.

6. Cohn M.A., Fredrickson B.L., Brown S.L., Mikels J.A., Conway A.M. Happiness unpacked: positive emotions increase life satisfaction by building resilience. Emotion. 2009;9:361. doi: 10.1037/a0015952.

7. Goleman, D. (1995). Emotional intelligence: Why it can matter more than IQ. New York, NY: Bantam Books.

8. Goleman D. The Brain and Emotional Intelligence: New Insights. In: Satpute A., editor. More than sound LLC. Regional Business; Northampton, MA, USA: 2011

9. KADAMBARI, ; SINGH, Swati. A Correlational Study of Emotional Intelligence and Resilience among Adults. International Journal of Education and Management Studies, [S.1.], p. 78-82, mar. 2015. ISSN 2321-3671.

10. Magnano P., Craparo G., Paolillo A. Resilience and Emotional Intelligence: which role in achievement motivation. Int. J. Psychol. Res. 2016;1:9-20. doi: 10.21500/20112084.2096.

11. Robinson, A.C.; Downey, L.A.; Ford, T.C.; Lomas, J.E.; Stough, C. Green teens: Investigating the role of emotional intelligence in adolescent environmentalism. Personal. Individ. Differ. 2019, 138, 225-230 


\section{International Advanced Research Journal in Science, Engineering and Technology}

Vol. 8, Issue 8, August 2021

DOI: $10.17148 /$ IARJSET.2021.8818

12. Salovey P, Mayer JD. Emotional Intelligence. Imagination, Cognition and Personality. 1990;9(3):185-211. doi:10.2190/DUGG-P24E52WK-6CDG

13. Schutte, N.S., Malouff, J.M., Hall, L.E., Haggerty, D.J., Cooper, J.T., Golden, C.J., et al. (1998). Development and validation of a measure of emotional intelligence. Personality and Individual Differences, 25, 167-177.

14. Wong M.M. Perceptions of Parental Involvement and Autonomy Support: Their Relations with Self-Regulation, Academic Performance, Substance Use and Resilience among Adolescents. N. Am. J. Psychol. 2008;10:3.

15. Trigueros, R.; Aguilar-Parra, J.M.; Álvarez, J.F.; González-Bernal, J.J.; López-Liria, R. Emotion, Psychological Well-Being and Their Influence on Resilience. A Study with Semi-Professional Athletes. Int. J. Environ. Res. Public Health 2019, 21, 4192.

16. Pooja Dahiya; Roopsi Kaushik; Anil Sindhu. "Corona virus: an Overview Along with Its Alternative Diagnostic Measures". International Research Journal on Advanced Science Hub, 2, Special Issue ICARD 2020, 2020, 163-169. doi: 10.47392/irjash.2020.113

17. Siddavatam rammohan reddy; Balaji krushna potnuru. "3D Printing Innovation during Covid-19 Pandemic". International Research Journal on Advanced Science Hub, 2, 8, 2020, 62-67. doi: 10.47392/irjash.2020.95

18. Remya S. "Covid19 and Environment-A Theoretical Review from Higher Education Students Perspective". International Research Journal on Advanced Science Hub, 2, Special Issue ICARD 2020, 2020, 227-230. doi: 10.47392/irjash.2020.124

19. Yeshi Ngima; Dorjee Tsering. "Impact of COVID-19 on Education". International Research Journal on Advanced Science Hub, 2, Special Issue ICAMET 10S, 2020, 34-39. doi: 10.47392/irjash.2020.196

20. Menonjyoti Kalita; Golam Imran Hussain. "Determining the Influencing Factors of COVID 19 on Mental Health Using Neural Network". International Research Journal on Advanced Science Hub, 3, Special Issue 6S, 2021, 126-129.

21. Ajitha K; Samuel Joseph C; Mahila Vasanthi Thangam D. "Online marketing of agricultural products during COVID pandemic: Farmers and customers perspectives". International Research Journal on Advanced Science Hub, 3, Special Issue 6S, 2021, 94-101. 